$2013 / 24$

\title{
Quality Improvement Using Taguchi’s Model:- A Casy Study from Serbia
}

\author{
Vidosav D. Majstorovic ${ }^{1}$, Tatjana Sibalija ${ }^{2},{ }^{1-2}$ University of Belgrade
}

\begin{abstract}
The developed Taguchi's model for the multiobjective process design could incorporate customers' specifications for several characteristics and could be used to optimise various types of manufacturing processes. The goals of the model implementation areis is to find the optimal process parameter settings and to reduce the influence of noise factors, to ensure the achievement of the specified product characteristic values and to reduce variations. The model is given in a form of an hybrid intelligent system for the process design (optimisation, modelling and/or simulation), providing the possibility for learning features (learning from the experimental or from the historical data).
\end{abstract}

Keywords: knowledge-based system, robust system, quality loss, genetic algorithm, improvement.

\section{INTRODUCTION}

The approach of Taguchi's robust design has been successfully used in many single-response process design problems. However, to date, the original Taguchi's method has not been proven fully functional for optimising the multiobjective problems; the sole path was relying on engineers' judgement. There are several recent approaches to multiresponse design based on Taguchi's static robust design, actually on the transformation of Taguchi's quality loss function [1] or Taguchi's SN ratio [2] that considers correlation among responses employing the principal component analysis (PCA) to make them uncorrelated. Approaches that combine the PCA and grey relational analysis (GRA) transform responses into a single measure [3, 4]. However, the mentioned approaches, considering only components in PCA in which variance (eigenvalue) is greater than or equal to one, imply the larger portion but not the total variance of responses. Hence, they do not provide the totally objective way of an analysis. Detailed discussion regarding the mentioned and other related approaches to multi-response optimisation can be found in reference [5]. In current practice, the multi-response process design is usually performed by response surface methodology (RSM). Although proven effective in many cases, RSM does not enable simultaneous optimisation of both mean and variance of the responses, RSM model may not find the global best solution and might be trapped easily in a local minimum.

Also, it does not discuss the correlations among responses. Several authors employed ANNs to design complex industrial processes [6]. The approaches based on the desirability function analysis (DFA) and ANN combine the advantages of both techniques [7], but it has been commented that the approaches based on the DFA do not always provide the global optimal solution. Hybrid approaches, based on the
ANN and GA, were developed to solve different process design or optimisation problems [8]. The approach that uses DFA in Pareto front genetic optimisation [9] was used to optimise the dynamic multi-objective problem, assuming a known analytical model of the process. Application of GA was also combined with the RSM methodology [10]. There are a few approaches found in the literature that are based on the application of GA and designed to solve one particular problem $[11,12]$ and, hence, they are not suitable for general application.

\section{II.TAGUCHI'S MODEL - OUR APPROACH}

The developed model that intends to overcome the deficiencies of the above methods is composed of three modules [13]. Module 1: Design of experiment by expert system: The purpose of the expert system for the design of experiments is to generate the experimental plan by selecting an inner orthogonal array (OA), with respect to the number of control factors and levels, and an outer array with respect to the number of noise factors and levels used in the experiment. In the developed rule-based expert system, rules for the array selection are formed using 'If-Then' rules. The specific importance value is associated with each rule. Conflict resolving is based on the 'highest priority rule' technique. The reasoning is performed by using the forward chaining inference. According to the user input for the number of control and noise factors and their levels, the expert system selects inner and outer arrays to form the experimental plan. Experiment is carried out and responses are measured for all experimental trials. Module 2: Experimental data preprocessing and analysis. The second module presents a Taguchi-based statistical approach to the processing and analysis of the obtained experimental data (or historical data about the process). The measured response values are transformed into corresponding Taguchi's quality losses (QL). The QL presents a financial measure of the customer dissatisfaction with a response as it deviates from a specified value. In general case, the quality characteristics of a product are correlated, as well as the corresponding QLs, so it is necessary to make them uncorrelated. Principal component analysis (PCA) is performed over normalised QL data (NQL) to obtain a set of uncorrelated components. Then, the grey relational analysis (GRA) is used to syntheses the obtained components into a single measure with respect to their weights in PCA. GRA main function is to indicate the relational degree between the current data sequence and the ideal sequence (in this case, the ideal sequence is: $\mathrm{QL}=0$ ). The obtained grey relational grade $(\gamma \mathrm{k})$ is adopted as the synthetic performance 
measure that adequately takes into account all, possibly correlated, responses with respect to the customer specifications. The weights used for determining $\gamma \mathrm{k}$ are based on the total variance of original responses, which maximise the objectivity of the analysis. Knowing $\gamma \mathrm{k}$ and factor (parameter) values, it is possible to calculate the effects of factors on the $\gamma \mathrm{k}$ for all factor levels used in the experiment. The optimal parameter conditions can be obtained by selecting the maximum of factor effects on the synthetic measure $(\gamma \mathrm{k})$. By applying the factor effects approach can find the optimal parameters solution from the parameter values used in experimental trials, hence in could not provide the overall global solution found in a continual space. However, the factor effects solution presents the bases for the ANN\&GA module development. Module 3: Solution process modelling and optimisation. In order to integrate knowledge into the processes design, artificial intelligence techniques are employed. Artificial neural networks (ANNs) are used to learn the process behaviour, to establish the relationship between the process parameters and the synthetic performance measure $\gamma \mathrm{k}$. By using the trained neural model, a genetic algorithm (GA) is employed to find the global optimal process parameter setting. ANN is a powerful technique to generate complex multi-response models without referring to a particular mathematical model, proven effective in various applications. By applying ANN to learn the process behaviour, process is considered a 'black-box' and it does not require any prior knowledge about process interrelationships. Since the process modelling is the most sensitive part of the proposed model, several ANNs with different architectures are developed for each problem, and the best ANN is selected according to the minimal mean-square-error (MSE) criteria. A GA is proven as a potent multiple-directional heuristic search method for optimising highly nonlinear, non-convex, multi-modal and complex functions. It is less likely to get trapped in a local optimum than the traditional optimisation methods. The ANN model presents an objective function for GA, wich, by maximising the objective function, finds the optimal process parameter settings in a continual space. In this model, GA initial population is set in a neighbourhood of a potentially good solution - the factor effects solution. This is of a particular significance for the model efficiency, because it maximises the capability of GA to find the actual global optimum in a given number of generations. If the initial population is generated randomly, it can not be guaranteed that GA will find the actual global optimum in a limited number of generations. Since it has been proven that the choice of the basic GA operations (selection and crossover) depends on the application, several GAs with different operation types are tested for each problem. The best GA is chosen according to the maximal fitness $(\gamma)$ criteria and its solution is adopted as a final one. This feature provides the acceptance of specifics of each particular problem and enhances the generality of the model. The GA considers all continual parameter values between corresponding bounds, in contrast to traditional experimental methods that consider only discrete values used in the experiment or in historical data. Relying on this fact and setting the GA parameters properly, the proposed model ensures the optimal performance of GA to converge to a global, rather than a local optimum.

\section{EXPERIMENTAL RESULTS AND DISCUSSION}

The analysis of several experimental results [13-15], confirms the effectiveness of the model to solve various types of multi-objective problems in process design, optimisation and/or modelling. In this paper, two case studies are presented in brief. Case study 1. The goal of the first study was to select the optimal settings of control parameters (factors) of automatic enamelling process in cookware production. Instead of conducting the actual experiment, it was decided to optimise the process using historical data from the process control charts. Two correlated quality characteristics were followed and monitored by the control charts; both are continuous measurable variables of the NTB type, as follows: base enamel thickness (t1) $[\mu \mathrm{m}]$ (target is $100[\mu \mathrm{m}])$ and the cover enamel thickness (t2) $[\mu \mathrm{m}]$ (target is $240[\mu \mathrm{m}])$. Six control factors, noted in the control charts, were considered: (1) base enamelling parameters: deposit weight (DW1) [g/cm3], specific weight (SW1) $[\mathrm{g} / \mathrm{cm} 3]$ and automat speed (AS1) [parts/min]; and (2) cover enamelling parameters: deposit weight (DW2) [g/cm3], specific weight (SW2) $[\mathrm{g} / \mathrm{cm} 3]$ and automat speed (AS2) [parts/min]. From the control charts data, normalisation of QL values was performed with respect to the maximal QL found in $\mathrm{k}$ points of a data set and the ideal case where $\mathrm{QL}=0$ (Table 1). PCA was performed on NQLs and scores were computed by considering both principal components, in contrast to the common approach ([1]), where only the first component would be considered enclosing only $51.6 \%$ of the total variance. Next, $\gamma \mathrm{k}$ values were calculated (Table 2 ) where the weights $\omega$ i were $[0.516 ; 0.484]$. Knowing $\gamma \mathrm{k}$ and the factor values, the factor effects were tabulated giving the optimal solution: DW1 = 1.70; SW1 = 11; $\mathrm{AS} 1=6 ; \mathrm{DW} 2=1.71 ; \mathrm{SW} 2=11 ; \mathrm{AS} 2=8$.

Process modelling was performed by using ANNs. The network 6-5-1 showed the least error $(\mathrm{MSE}=0.000588)$ and it was selected to present the process model. Then, nine GAs were developed (Table 2): the initial population was seeded close to the factor effects solution; population size was 30 . All tested GAs showed the same result in terms of the best fitness value $(\gamma=0.8211)$ and the optimal parameters setting (adopted as a final solution): $\mathrm{DW} 1=1.70 ; \mathrm{SW} 1=11 ; \mathrm{AS} 1=5$; DW2 = 1.71; SW2 $=11 ; \mathrm{AS} 2=9$. Results of GAs shows robustness with respect to GA own settings. All GAs converged to the optimal solution in the first generation, which is the consequence of a good-seeded initial population [15].

From Table 3 it could be seen that the intelligent model resulted in a better solution than the factor effects due to a search over continual space. Since the actual experiment was not conducted, it was not possible to analyse these data using RSM. 
TABLE 1

THE NQLS, PRINCIPAL COMPONENT SCORES AND A MULTI-RESPONSE PERFORMANCE MEASURE

\begin{tabular}{|l|l|l|l|l|l|l|l|l|l|l|l|}
\hline No. & DW1 & SW1 & AS1 & DW2 & SW2 & AS2 & $N Q L_{t 1}$ & $N Q L_{t 2}$ & $Y_{1}(k)$ & $Y_{2}(k)$ & $\gamma_{k}$ \\
\hline 1 & 1.69 & 10 & 8 & 1.72 & 11 & 7 & 0,6447 & 0,1583 & 0,3438 & 0,5677 & 0,490599 \\
\hline 2 & 1.69 & 10 & 8 & 1.73 & 12 & 7 & 0,8298 & 0,1563 & 0,4762 & 0,6972 & 0,424873 \\
\hline$\ldots$ & $\ldots$ & $\ldots$ & $\ldots$ & $\ldots$ & $\ldots$ & $\ldots$ & $\ldots$ & $\ldots$ & $\ldots$ & $\ldots$ & $\ldots$ \\
\hline 54 & 1.70 & 10 & 6 & 1.71 & 11 & 8 & 0,3329 & 0,3145 & 0,0130 & 0,4577 & 0,772257 \\
\hline
\end{tabular}

TABLE 2

GAS SETTINGS AND RESULT

\begin{tabular}{|l|l|l|l|l|l|l|l|l|l|l|}
\hline GA & GA1 & GA2 & GA3 & GA4 & GA5 & GA6 & GA7 & GA8 & GA9 \\
\hline selection function & $\begin{array}{l}\text { stochast. } \\
\text { uniform }\end{array}$ & $\begin{array}{l}\text { roulette } \\
\text { wheel }\end{array}$ & $\begin{array}{l}\text { tourna- } \\
\text { ment }\end{array}$ & $\begin{array}{l}\text { stochas. } \\
\text { uniform }\end{array}$ & $\begin{array}{l}\text { roulette } \\
\text { wheel }\end{array}$ & $\begin{array}{l}\text { tourna- } \\
\text { ment }\end{array}$ & $\begin{array}{l}\text { stochast. } \\
\text { uniform }\end{array}$ & $\begin{array}{l}\text { roulette } \\
\text { wheel }\end{array}$ & tourna-ment \\
\hline crossover function & \multicolumn{2}{|l|}{ single point } & \multicolumn{1}{l|l}{ two point } & \multicolumn{2}{l|}{ arithmetic } \\
\hline Max. fitness & 0,8211 & 0,8211 & 0,8211 & 0,8211 & 0,8211 & 0,8211 & 0,8211 & 0,8211 & 0,8211 \\
\hline DW1 & 1,7 & 1,7 & 1,7 & 1,7 & 1,7 & 1,7 & 1,7 & 1,7 & 1,7 \\
\hline SW1 & 11 & 11 & 11 & 11 & 11 & 11 & 11 & 11 & 11 \\
\hline AS1 & 5 & 5 & 5 & 5 & 5 & 5 & 5 & 5 & 5 \\
\hline DW2 & 1,71 & 1,71 & 1,71 & 1,71 & 1,71 & 1,71 & 1,71 & 1,71 & 1,71 \\
\hline SW2 & 11 & 11 & 11 & 11 & 11 & 11 & 11 & 11 & 11 \\
\hline AS2 & 9 & 9 & 9 & 9 & 9 & 9 & 9 & 9 & 9 \\
\hline
\end{tabular}

TABLE 3

COMPARATIVE ANALYSIS OF THE RESULTS OBTAINED BY DIFFERENT METHODS

\begin{tabular}{|l|l|l|l|l|}
\hline Method & RSM & Antony $[1]$ & The factor effects & The process designer \\
\hline Optimal setting & - & {$[1.68 ; 9 ; 8 ; 1.73 ; 12 ; 7]$} & {$[1.70 ; 11 ; 6 ; 1.71 ; 11 ; 8]$} & {$[1.70 ; 11 ; 5 ; 1.71 ; 11 ; 9]$} \\
\hline$\gamma$ & - & 0.4179 & 0.7647 & 0.8211 \\
\hline
\end{tabular}

TABLE 4

THE NQLS, PRINCIPAL COMPONENT SCORES AND A MULTI-RESPONSE PERFORMANCE MEASURE

\begin{tabular}{|c|c|c|c|c|c|c|c|c|c|c|}
\hline \multicolumn{2}{|l|}{ No. } & BP1g & BF $1 \mathrm{~g}$ & $N Q L_{B S}$ & $N Q L_{D}$ & $N Q L_{H}$ & $Y_{1}(k)$ & $Y_{2}(k)$ & $Y_{3}(k)$ & $\gamma_{k}$ \\
\hline \multirow{4}{*}{ M1 } & 1 & 55 & 85 & 0,9604 & 0,8890 & 0,9516 & 1,6136 & $-0,0069$ & $-0,1194$ & 0,526320 \\
\hline & 2 & 65 & 85 & 0,1678 & 0,5062 & 0,3748 & 0,5801 & 0,1202 & $-0,2717$ & 0,587084 \\
\hline & $\ldots$ & $\ldots$ & $\ldots$ & $\ldots$ & $\ldots$ & $\ldots$ & $\ldots$ & $\ldots$ & $\ldots$ & $\ldots$ \\
\hline & 14 & 65 & 115 & 0,1421 & 0,5235 & 0,5554 & 0,6718 & 0,0133 & $-0,3888$ & 0,636230 \\
\hline \multirow{4}{*}{ M2 } & 1 & 55 & 85 & 0,9884 & 0,8978 & 0,9964 & 1,6610 & $-0,0311$ & $-0,1244$ & 1,000000 \\
\hline & 2 & 65 & 85 & 0,1728 & 0,2670 & 0,5629 & 0,5618 & $-0,1833$ & $-0,2624$ & 0,373331 \\
\hline & $\ldots$ & $\ldots$ & $\ldots$ & $\ldots$ & $\ldots$ & $\ldots$ & $\ldots$ & $\ldots$ & $\ldots$ & $\ldots$ \\
\hline & 14 & 65 & 115 & 0,1752 & 0,2094 & 0,4854 & 0,4905 & $-0,1744$ & $-0,1977$ & 0,576955 \\
\hline
\end{tabular}

Case study 2. The goal of the second case study was to establish a process parameter window of a gold wire bonding process in a semiconductor industry, for the whole group of machines. It was noticed that performing the process with the same set of parameter values on different machines gave different response values. The machine 1 (M1) was adopted as the representative of a group of machines with the same behaviour. The behaviour of machine 2 (M2) significantly deviated from the rest of the group. The main process parameters were considered in the experiment and varied on three levels: Base Power (BP1g): 55; 65 and 75 [mW]; and Base Force (BF1g): 85; 100 and 115 [gf]. Three correlated responses of the nominal-the-best (NTB) type, were observed: the strength of intermetallic connections expressed over the bond shear test (BS) [gf] (target is 270 [gf]), the shape of the bond expressed over bond diameter (D) [ $\mu \mathrm{m}]$ (target is 193 $[\mu \mathrm{m}])$ and bond height $(\mathrm{H})[\mu \mathrm{m}]($ target is $50[\mu \mathrm{m}])$.

Since two control factors varied on three levels, ES generated the experimental plan with 9 trials, and 5 repetitions were added. The experiment results responses - were measured and transformed into NQLs (Table 4). PCA was applied considering all three components to enclose the total variance. By using the common rule to take into account only components with eigenvalue greater than 1 ([1]), only $66.7 \%$ of the total variance for M1 and $91.5 \%$ of the total variance for M2 would be enclosed. The grey relational grade $\gamma \mathrm{k}$ was than 
computed (Table I), where the weights $\omega$ i for M1 were [0.667; $0.246 ; 0.087$ ] and for M2 were [0.915; 0.066; 0.019], for the first, the second and the third responses, respectively. Finally, the optimal solution for both machines, by the factor effects approach, was: BP1g=75; BF1g = 100.).

The set of ANNs was trained in order to model the relationship between the synthetic performance measure $\gamma \mathrm{k}$ and process parameters, for M1 and M2 separately. Each of the networks has two neurons (two process parameters) in the input layer and one neuron $(\gamma \mathrm{k})$ in the output layer. The number of neurons in the hidden layer varies from 1 to 9 . The best results were shown by ANN 2-9-1 (MSE=0.000189) for $\mathrm{M} 1$ and $\mathrm{ANN}$ 2-9-1 (MSE=0.000148) for $\mathrm{M} 2$, presenting inputs for GAs. Then, nine GAs were developed for each machine (Table 5): the initial population was seeded close to the factor effects solution; population size was 10. For M1, GA1 and GA4 resulted in the best fitness $(\gamma=0.88120)$ and the optimal setting: $\mathrm{BP}=85 ; \mathrm{BF} 1=99$. The best results in terms of the best fitness $(\gamma=0.71277)$ were achieved by GA2 and GA5 for M2, giving the optimal setting: $\mathrm{BP}=85$; $\mathrm{BF} 1=95$. From Table 5 it is visible that all tested GAs show similar results in terms of the fitness value $(\gamma)$ and the optimal parameters for M1. However, for M2, the significant difference in BF1g values could be noticed. It can be concluded that the "tournament" selection and the 'arithmetic" crossover are not adequate for the observed problem for M2. This proves the necessity to consider different GA basic functions for each problem. For M1, all GAs converged early to the global optimum. For M2, GA2 converged to the best solution in the 1050th generation and GA5 in the 710th generation. The observed difference in a speed of convergence of GAs between M1 and M2 has proven the initial indication that M2 interrelations are more complex than on the other machines. The finally established process parameters window is: $\mathrm{BP} 1 \mathrm{~g}=85 ; \mathrm{BP} 1 \mathrm{~g}=95 \div 99$ [14].

Results of application of the proposed factor effects approach and the intelligent process designer model in comparison with RSM and Anthony's approach ([1]) are presented in Table 6. The factor effects approach has shown better results than RSM and Anthony's approach, because it considers correlations among responses and involves the total variance of the original response values. This is further improved by the intelligent process designer model, for both machines, due to the fact that it searches for the optimal solution in a continual multi-dimensional space.

TABLE 5

GAS SETTINGS AND RESULTS

\begin{tabular}{|c|c|c|c|c|c|c|c|c|c|c|}
\hline \multicolumn{2}{|l|}{ GA } & GA1 & GA2 & GA3 & GA4 & GA5 & GA6 & GA7 & GA8 & GA9 \\
\hline \multicolumn{2}{|c|}{ selection function } & $\begin{array}{l}\text { stochast. } \\
\text { uniform }\end{array}$ & $\begin{array}{l}\text { roulette } \\
\text { wheel }\end{array}$ & $\begin{array}{l}\text { tourna- } \\
\text { ment }\end{array}$ & $\begin{array}{l}\text { stochas. } \\
\text { uniform }\end{array}$ & $\begin{array}{l}\text { roulette } \\
\text { wheel }\end{array}$ & $\begin{array}{l}\text { tourna- } \\
\text { ment }\end{array}$ & $\begin{array}{l}\text { stochast. } \\
\text { uniform }\end{array}$ & $\begin{array}{l}\text { roulette } \\
\text { wheel }\end{array}$ & tourna-ment \\
\hline \multicolumn{2}{|c|}{ crossover function } & \multicolumn{3}{|c|}{ single point } & \multicolumn{3}{|c|}{ two point } & \multicolumn{3}{|c|}{ arithmetic } \\
\hline \multirow{3}{*}{ M1 } & Max. fitness & 0,8812 & 0,8809 & 0,8807 & 0,8812 & 0,8809 & 0,8807 & 0,8808 & 0,8808 & 0,8807 \\
\hline & BP1g & 85,00 & 85,00 & 85,00 & 85,00 & 85,00 & 85,00 & 85,00 & 85,00 & 85,00 \\
\hline & BF1g & 98,97 & 99,81 & 100,0 & 98,96 & 99,83 & 100,0 & 99,95 & 99,95 & 100,00 \\
\hline \multirow{3}{*}{ M2 } & Max. fitness & 0,7082 & 0,7128 & 0,7081 & 0,7101 & 0,7128 & 0,7081 & 0,7081 & 0,7081 & 0,7081 \\
\hline & BP1g & 85,00 & 85,00 & 85,00 & 85,00 & 85,00 & 85,00 & 85,00 & 85,00 & 85,00 \\
\hline & BF1g & 99,75 & 94,96 & 100,00 & 96,97 & 94,96 & 100,00 & 99,94 & 99,96 & 100,00 \\
\hline
\end{tabular}

TABLE 6

COMPARATIVE ANALYSIS OF THE RESULTS OBTAINED BY DIFFERENT METHODS

\begin{tabular}{|c|c|c|c|c|c|c|c|c|}
\hline Method & & \multicolumn{3}{|c|}{ M1 } & & \multicolumn{3}{c|}{ M2 } \\
\hline & RSM & Antony [1] & $\begin{array}{c}\text { The factor } \\
\text { effects }\end{array}$ & $\begin{array}{c}\text { The process } \\
\text { designer }\end{array}$ & RSM & $\begin{array}{c}\text { Antony [1] } \\
\text { The factor } \\
\text { effects }\end{array}$ & $\begin{array}{c}\text { The process } \\
\text { designer }\end{array}$ \\
\hline $\begin{array}{c}\text { Optimal } \\
\text { setting }\end{array}$ & {$[65 ;$} & {$[65 ;$} & {$[75 ;$} & {$[85 ;$} & {$[65 ;$} & {$[65 ; 115]$} & {$[75 ;$} & {$[85 ;$} \\
\hline$\gamma$ & 0.6303 & 0.6303 & 0.6395 & 0.8812 & 0.6379 & 0.5736 & 0.6463 & 0.7127 \\
\hline
\end{tabular}

\section{CONCLUSION}

In order to strengthen a 'knowledge-based' paradigm in a process design, an integrative, generic and intelligent model for multi-response process design was developed. The outcome of the model is a single process parameters setting that simultaneously meets the specifications of all responses, considering all possible solutions in a continual space. The presented model does not imply any assumptions regarding the type of process or process parameters, type of responses, type of relations between responses and process parameters and existence of interactions among them. From another point of view, the model takes into consideration specific features of each multi-objective problem. The model also provides the possibility to predict the value of a performance measure for the given process parameter settings. The analysis of the application of the process designer indicated that it showed better results, in terms of the optimal parameter settings that yielded the maximal synthetic performance measure, than the other methods [13-16]. Based on the above results, it might be expected that the model implementation could contribute to the transition from the 'experience or assumption- based' to the 'knowledge-based system' decision making in a multiobjective design of manufacturing processes. 


\section{REFERENCES}

[1] J. Antony, Multi-response optimization in industrial experiments using Taguchi's quality loss function and principal component analysis. Qual Reliab Eng Int, 16, 3--8 (2000). http://dx.doi.org/10.1002/(SICI)10991638(200001/02)16:1<3::AID-QRE276>3.0.CO;2-W

[2] C.P. Fung and P.C. Kang, Multi-response optimization in friction properties of PBT composites using Taguchi method and principle component analysis. J Mater Proc Technol, 170, 602--610 (2005). http://dx.doi.org/10.1016/j.jmatprotec.2005.06.040

[3] C.H. Wang, L.I. Tong, Optimization of Dynamic Multi-Response Problems Using Grey Multiple Attribute Decision Making. Quality Engineering, 17, 1--9 (2005). http://dx.doi.org/10.1081/QEN-200028450

[4] F.C. Wu, Optimising robust design for correlated quality characteristics. Int J Adv Manuf Technol, 24, 1--8 (2004)

[5] T. Sibalija, V. Majstorovic, Multi-response optimisation of thermosonic copper wire-bonding process with correlated responses. Int $\mathrm{J} \mathrm{Adv}$ Manuf Technol, 42, 363--371 (2009). http://dx.doi.org/10.1007/s00170008-1595-1

[6] L. M. Galantucci, L. Tricarico, R. Spina, A quality evaluation method for laser welding of Al alloys through neural networks. CIRP Annals, 49, 131--134 (2000). http://dx.doi.org/10.1016/S0007-8506(07)62912-6

[7] C.M. Hsu, C.T. Su, D. Liao, Simultaneous optimisation of the broadband tap coupler optical performance based on neural networks and exponential desirability functions. Int J Adv Manuf Technol, 23 896--902 (2004). http://dx.doi.org/10.1007/s00170-003-1733-8

[8] L.M. Galantucci, G. Percoco, R. Spina, An artificial intelligence approach to the registration of free-form shapes. CIRP Annals, 53,139142 (2004). http://dx.doi.org/10.1016/S0007-8506(07)60663-5

[9] R. Roy, J. Mehnen, Dynamic multi-objective optimisation for machining gradient materials. CIRP Annals, 57, 429--432 (2008). http://dx.doi.org/10.1016/j.cirp.2008.03.020

[10] D. Drain, W.M. Carlyle, D.C.Montgomery, C. Borror, C. AndersonCook, A Genetic Algorithm Hybrid for Constructing Optimal Response Surface Designs. Qual Reliab Eng Int, 20, 637--650 (2004). http://dx.doi.org/10.1002/qre.573

[11] K.W. Tong, C.K. Kwong, K.M. Yu, Intelligent process design system for the transfer moulding of electronic packages. Int J Prod Res, 42, 1911-1931 (2004). http://dx.doi.org/10.1080/00207540310001652860

[12] T.H. Hou, S.H. Chen, T.Y. Lin, K.M. Huang, An integrated system for setting the optimal parameters in IC chip-package wire bonding processes. Int J Adv Manuf Technol, 30, 247-253 (2006). http://dx.doi.org/10.1007/s00170-005-0083-0
[13] T. Sibalija, V. Majstorovic, Z. Miljkovic, An intelligent approach to robust multiresponse process design. Int J Prod Res (2011), vol. 49 No. 17, pp. 5079-5097. http://dx.doi.org/10.1080/00207543.2010.511476

[14] T. Sibalija, V. Majstorovic, An integrated simulated annealing-based method for robust multiresponse process optimization, Int J Adv Manuf Technol, 201259 (9-12):1227-1244. http://dx.doi.org/10.1007/s00170011-3572-3

[15] T. Sibalija, V. Majstorovic, M. Sokovic, Taguchi-based and intelligent optimisation of a multi-response process using historical data, Strojniski Vestnik - Journal of Mechanical Engineering, (2011), vol. 57 br. 4, str. 357-365.

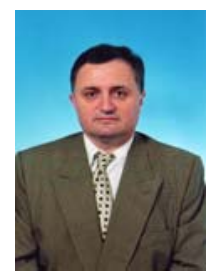

Vidosav Majstorovic is a Full Professor and the Head of Laboratory for Production Metrology and TQM, at the Faculty of Mechanical Engineering, University of Belgrade. He has published over 500 scientific papers on international conference, journals and book chapter, and 35 books. He was involved in more than 280 research and commercial projects for industry.He is a member of CIRP, IMCEO, IFIP, IFAC, ASQ and EOQ, and founder and chairman of the International Conference "Total Quality Management: Advanced and Intelligent Approaches". He is also reviewer of many peer-reviewed international conferences and journals and FP6/7 expert. His research interests include quality control and management, production metrology, manufacturing technologies, expert systems, AI, business excellence, etc.

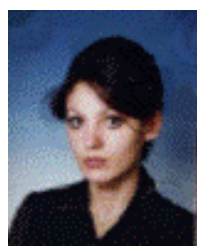

Tatjana Sibalija is an Associate Professor at the Faculty of International Management Engineering, European University, Belgrade.

Research interests include production and industrial engineering, artificial intelligence, quality management \& engineering, multi-objective optimisation, six sigma, etc. She was involved in several national and international research and commercial projects for the industry. She is the author of 3 books and over 50 scientific papers published in peer-reviewed international journals / presented at international conferences; she is also reviewer of many peer-reviewed international journals and conferences, and FP7 expert.

Vidoslavs Majstorovics, Tatjana Sibalija. Kvalitātes uzlabošana, izmantojot Taguči modeli, - Serbijas piemērs

Izstrādāto Taguchi modeli par vairāku objektīvu procesu projektēšanu varētu iekḷaut klientiem paredzētajās specifikācijā pēc vairākām pazīmēm, un to varētu izmantot, lai optimizētu dažādu veidu ražošanas procesus. Model̦a ieviešanas mērķis ir atrast optimālo procesu parametru uzstādījumus un samazināt trokšņu faktora ietekmi, lai panāktu noteiktus produktu raksturlielumus un samazinātu atšḳirības. Modelis ir dots hibrīdo intelektuālo sistēmu veidā projektēšanas procesam (optimizācija, modelēšana un / vai simulācija), nodrošinot iespēju pētīt atšīrības (mācoties no eksperimentālā vai no vēsturiskajiem datiem).

\section{Видослав Майстрович, Татьяна Сибалия. Улучшение качества с использованием модели Тагути - одного примера из Сербии}

Разработанная модель Тагути для мульти-объективного процесса разработки может быть включена в заказ для нескольких характеристик и может быть использована для оптимизации различных видов производственных процессов. Целью реализации модели является поиск оптимальных значений параметров процесса и уменьшение влияния шума факторов, в целях обеспечения достижения указанных значений, характерных для продукции и уменьшить вариации. Модели задается в виде гибридных интеллектуальных систем для процесса проектирования (оптимизация, моделирование и / или моделирования), обеспечивая возможность для изучения особенностей (обучение по экспериментальным или исторических данных). 